\title{
Svět se mění nenápadně
}

Pro titulek úvodního slova k druhému ročníku semináře Geoinformatika jsem si vypůjčil název stejnojmenné knihy Jaroslava Žáka. Na našem prvním setkání v červnu 2006 jsme informovali o otevření našeho nového oboru Geoinformatika, v rámci studijního programu Geodézie a kartografie, o našich plánech a očekáváních.

Jestliže budu dnes opět hovořit $\mathrm{v}$ úvodu k semináři o uplynulém roku především z našeho pohledu, pohledu studijního programu Geodézie a kartografie, pak je to proto, že podobná setkání jsou pro nás cenným zdrojem inspirace a ponaučení a snad naše zkušenosti mohou být ve srovnání inspirací i pro naše kolegy.

Za jeden rok se toho př́liš nezměnilo a pokud ano, pak změny byly nenápadné. Jednak se nám podařilo víceméně sjednotit první ročníky oborů Geodézie a kartografie a Geoinformatika. Pro nový obor to především znamenalo doplnění dvou tradičních předmětů Aplikovaná optika a Elektronické metody, do oboru Geodézie a kartografie byl naopak do druhého semestru nově zařazen úvodní kurz Databázové systémy. Protože kapacita studijních plánů je omezená, došlo $\mathrm{k}$ redukci jednoho ze společenskovědních předmětů prvního ročníku.

V konkurenci nabídky různých škol a studijních oboru je podle mého názoru nezbytné, aby př́buzné i stejné obory různých škol byly jasně profilovány, různost je cennější než uniformita. Základem oboru Geoinformatika na stavební fakultě ČVUT je pochopitelně akcent na geodezii, zařazení předmětů Aplikovaná optika a Elektronické metody je plně v souladu s našim technickým zaměřením.

Zájem o nový obor geoinformatika se ve druhém roce nijak zásadně nezvýšil, opět budeme v prvním ročníku otevírat pouze dva kroužky. V nastávajícím akademickém roce 2007-2008 ale zároveň otevíráme první ročník magisterského studia geoinformatiky, především pro bakaláře našeho tradičního oboru Geodézie a kartografie. Do prvního ročníku se přihlásilo 16 studentư, což je řádově jedna čtvrtina všech absolventů.

V souvislosti s přechodem na strukturované studium pro náš studijní program vyvstává jistá komplikace v přijímaní bakalářů z jiných škol. Bakalářské studium je totiž na studijním programu Geodézie a kartografie Stavební fakulty ČVUT akreditováno jako čtyřleté. Je tedy otázka, jak řešit přijímání tř́letých bakalářủ do našich navazujících magisterských programů. Pokud neprokáží u přijímací zkoušky uchazeči znalosti v rozsahu, který vyžadujeme u našich bakalářù, mưže jim přijímací komise navrhnout přijetí do bakalářského studia na jeden rok a po úspěšném splnění individuálního studijního plánu pak přijetí do magisterského oboru.

Jestliže naše čtyřleté bakalářské obory představují jistou komplikaci pro mobilitu studentů, pak na druhé straně poskytují významně větší prostor pro odbornou přípravu bakalářù ve srovnání tříletými obory. Konkrétně získávají naši bakaláři ukončené vzdělání v katastru nemovitostí. V magisterských oborech se již katastr nevyučuje. 
Za jednu z absurdit naší doby považuji, že podle zeměměřického zákona (zák. č. 200/1994 Sb. v platném znění) se ale naši bakaláři nemohou ucházet o získání úředního oprávnění pro ověřování výsledků zeměměřických činností pro správu a vedení katastru nemovitostí.

Nikdo přitom nezpochybňuje jejich odbornou způsobilost, v zákoně je ale explicitně požadováno vzdělání alespoň magisterského studijního programu, pětiletá odborná praxe a složení zkoušky odborné způsobilosti. Zjevně naše společnost není na bakaláře ještě plně připravena. Věřím, že jde o přechodný stav, který nebude mít dlouhého trvání.

Zmiňuji zde tento případ proto, že jsem si jist, že nejde o jediný př́́klad, kdy je vysokoškolské bakalářské vzdělání degradováno zákonem, resortními předpisy či jen pouhou praxí a požadavky profesních komor. Evropská idea mobility pracovních sil a všeobecného uznávání vzdělání tak naráží na lokální administrativní překážky.

Na struktuře našich studentů se začíná projevovat působení státní školské politiky, která usiluje o zvýšení počtu vysokoškolsky vzdělaných obyvatel v populaci. Jde o celoevropský, resp. celosvětový, trend a nemá smysl s ním polemizovat. Navíc jde v principu o správný cíl. Protože ale nelze rozhodnutím ministerstva školství zároveň zvýšit průměrnou inteligenci populace, ani zajistit její vyšší pracovitost a píli, struktura našich studentů se nenápadně ale nezadržitelně mění.

Tradice a koeficienty ekonomické náročnosti na technických školách vedou k masové produkci studentů. V zásadě pro náš studijní program není problém počet zájemců o studium, ale jejich kvalita. Počty našich přijímaných studentů se přitom dlouhodobě drží řádově na stejné úrovni [6]. Skutečností ovšem je, že dnes přijímáme i studenty, kteří by před necelými deseti lety neměli nejmenší naději na přijetí. Stále přitom máme i výjimečné a skvělé studenty, v poslední době ale pozoruji trend, kdy podprůměrní studenti mají tendenci své nadanější kolegy demotivovat.

At̉ již máme jakékoli názory na e-learning a počítačem podporovanou výuku, je mimo jakoukoli diskusi, že jde o technologie, bez kterých se dlouhodobě neobejdeme. Zajímavý článek na téma e-learningu v oblasti geoinformatiky přednesli na semináři Scientia est potentia Petr Soukup a Pavel Žofka [3].

Jak jsem již zmínil, jednou z nenápadných změn v našich studijních plánech bylo sjednocení prvních dvou semestrů na oborech Geodézie a kartografie a Geoinformatika a v úvodním kurzu základů informatiky zařazení databází a SQL i pro geodety. Existuje snad bezpočet internetových kurzů a tutoriálů na dané téma, z nich ale svým způsobem vyniká A Gentle Introduction to SQL [4].

A Gentle Introduction to SQL nás s Janem Pytlem inspiroval k úvaze o založení vlastního podobného projektu SQLtutor, jehož pracovní alfa verze je k nahlédnutí na

$$
\text { http://josef.fsv.cvut.cz/cgi-bin/cepek/sqltutor }
$$

Implementace je přitom podružná, základní myšlenka projektu je sestavit sadu SQL úloh a z nich podle potřeby dynamicky generovat testy, resp. kvizy, se závěrečným bodovým hodnocením. Pokud se projekt ukáže jako životaschopný, budou pochopitelně zdrojové kódy zveřejněny pod GPL licencí, právě tak jako datové sady a otázky (zde přichází do úvahy licence GNU FDL). 
V úvodním kurzu se naši studenti seznamují s databází PostgreSQL (že šlo o dobrou volbu dokazuje mimo jiné i to, že pro přiští verzi ArcGIS připravuje firma ESRI rozš́iření o podporu databáze PostgreSQL). Pro praktické procvičování SQL používáme vývojové prostředí emacsu. Databáze otázek pro SQLtutora je generována z textových souborů ve formátu, který lze spouštět v emacsu pomocí sql-postgres módu. Veškeré otázky tedy mohou být zveřejněny jednak přes interaktivní přístup k databázi otázek, jednak zcela nezávisle jako jednoduché textové soubory, na které jsou studenti zvyklý ze cvičení.

Ideálním stavem by byla dostatečně rozsáhlá databáze otázek (později k SQL selectům plánujeme doplnit i operace insert, delete a update a otázky typu "autoškola", s výběrem odpovědí z dané nabídky), která by umožnila generování kvalitních testů. Pokud se podaří správně nastavit bodové ohodnocení náročnosti otázek, je možné použít systém jako formu zápočtové písemky, př́ípadně i jako filtr, který u zkoušky oddělí studenty, kteří mají např́íklad šanci se ucházet o výbornou. Při počtu řádově 120 studentů to může být významná úspora času a úsilí spojeného se zkoušením. Takto ušetřený čas lze věnovat individuální výuce a zkoušení nejlepších studenti̊.

SQLtutor předpokládá, že jednotlivé úlohy budou kategorizovány. Zavedení kategorií otázek přitom bude jedním z nejnáročnějších úkolů. Kvalitní kategorizace by ale byla cestou pro automatizované zkoušení, ve kterém by bylo možné ověřit, zda se např́klad student pouze zmýlil v jedné konkrétní otázce, nebo zda opravdu nerozumí jisté standardní úloze.

Při rekapitulaci uplynulého roku nesmím zapomenout na oslavy 300 let výročí založení ČVUT. Na oboru geodézie a kartografie jsme v rámci oslav uspořádali ve spolupráci s druhou komisí FIG mezinárodní symposium Scientia est potentia. Sborník recenzovaných referátů ze symposia byl vydán tiskem [5] a zároveň i v elektronické podobě. V druhém čísle časopisu Geoinformatics FCE CTU uvádíme tři příspěvky, které z časových důvodů nebyly publikovány ve sborníku [5] (autoři Karel Večeře, Václav Slaboch a Janis Strauhmanis).

Příprava a organizace mezinárodního symposia byla poměrně náročná a do značné míry šla na úrok př́pravy druhého ročníku workshopu Geoinformatika, který jsme museli přesunou na záríi. Tak jako minulý rok, tak i letos zajistil veškerou přípravu workshopu i vydání sborníku Martin Landa, kterému bych chtěl upřímně poděkovat (věřím, že nejen za sebe). Pokud se v organizaci druhého ročníku workshopu vyskytnou nějaké organizační potíže či nedostatky, pak plně padají na moji hlavu a předem se za ně omlouvám.

Aleš Čepek

19. zář́i 2007, Praha

[1] Jaroslav Žák, Svět se mění nenápadně, Nakladatelství Olympia, druhé vydání, Praha 1971, 132 stran

[2] Martin Landa, Aleš Čepek, eds.: Geoinformatics, Faculty of Civil Engineering, CTU Prague, sborník referátů [5], 183 pages, 2006, ISSN 1802-2669

[3] Petr Soukup and Pavel Žofka: Experience in the Application of E-learning Tools in Teaching, In Scientia est potentia, Czech Technical University, Prague, Czech Republic, 7-9 June, 2007, pp. 123-134. ISBN 978-80-01-03718-8

[4] A Gentle Introduction to SQL

http://www.sqlzoo.net/

Geinformatics FCE CTU 2007 
[5] Aleš Čepek ed.: Scientia est potentia, Proceedings of the symposium dedicated to the development of curricula organized jointly by FIG Commission 2 and the Faculty of Civil Engineering CTU in Prague, Prague, 7-9 June 2007, Published by the Czech Technical University in Prague. Printed by CTU Publishing House, ISBN 978-80-01-03718-8

http://geoinformatics.fsv.cvut.cz/wiki/index.php/Scientia_Est_Potentia_-_Download

[6] Aleš Čepek, Leoš Mervart, and Josef Kopejska. Motivace pro studium geoinformatiky. In Jiří Horák and Pavel Děrgel, editors, Sborník sympozia GIS Ostrava 2007. Hornicko-geologická fakulta, Institut geoinformatiky, VŠB - Technická univerzita Ostrava, 28.-31.1. 2007 